Journal of Social Sciences 6 (3): 320-323, 2010

ISSN 1549-3652

(C) 2010 Science Publications

\title{
The Buddha Images and Conservation and Adherence to Cultural Values in Northeast
}

\author{
${ }^{1}$ Athikan Suksri, ${ }^{1}$ Souneth Phothisane, ${ }^{1}$ Sastra Laoakka, ${ }^{2}$ Niwat Thongwol and ${ }^{3}$ Budsakorn Saenyabud \\ ${ }^{1}$ The Research Institute Northeastern of Art and Culture, Mahasarakham University, Thailand \\ ${ }^{2}$ Department of Philosophy and Religion, Faculty of Humanities and Social Science, \\ Rajabhat University, Nakhon Ratchasima, Thailand \\ ${ }^{3}$ Ban Kokkuay Nonghaew Wittaya School, Educational Service Area Office 3, Roi Et, Thailand
}

\begin{abstract}
Problem statement: This study is caused by the problem of conservation of the Buddha images to exist in the original condition and by the problem of transference and adherence to indigenous knowledge of local craftsmen. At present there have not yet been systematic and wide conservation and adherence to the Buddha images. Other causes are such as incorrect techniques of conserving the Buddha images, lack of encouraging people and the community to appreciate the Buddha images, incorrect techniques of restoring the Buddha images, lack of increment of economic and cultural values in terms of tourism, lack of correct techniques of studying styles of the Buddha images to rebuild the styles for the community to appreciate local art, lack of clear examination of the background and there have not been comparative studies to find out relationships with other localities. Purposes were to examine backgrounds of Isan Buddha images and iconology, to examine current conditions and problems of the Buddha images and to investigate models of conservation and adherence to cultural values in Iran. Study area covered Changwat Maha Sarakham, Changwat Kalasin and Changwat Roi Et where there have been long backgrounds and continuous developments of the Buddha image in all Ages. Approach: This study used qualitative methodology by collecting data from related literature and from field studies by interviews and focused group discussion from totally 66 informants. Findings were presented by means of a descriptive analysis. Results: The result of this research revealed that there were 5 models of the Buddha image art found in Isan: Sandstone Buddha images, baked-clay votive tablets, cast motar Buddha images, bronze Buddha images and wooden Buddha images. They were in the Periods of Dvaravati, Lop Buri and Lan Chang. The Buddha images were popularly built in many different styles such as concentration style, double-miracle style, nagover-his-head style, blessing style, world-opening style, relatives-stop style, dharma consideration style and others. In addition, they popularly made $4,9,12$ or 168 votive tablets on each of a large number of baked-clay plates. Significant characteristics of the Buddha images were different based on the outside influences they received. Conclusion: The Buddha images of the Dvaravati Period were influenced from India in the art styles of Kupta, Pala, Sena and Pallava to central of Thailand. Those of the Lop Buri Period were influenced by Khmer art. Those of the Lan Chang Period were influenced by Lan Chang art which had been influenced by Lan Na Savana. The bronze Buddha images were popularly made in the concentration style and the maravijaya style. The wooden Buddha images were popularly made in the styles of maravijaya, concentration, dharma consideration and others.
\end{abstract}

Key words: Buddha image characteristics, the Buddha image art, iconology, dharma philosophy

\section{INTRODUCTION}

The Buddha images are works involving objects of art discovered in Suvarnabhumi (Southeast Asia Peninsula). There have been many periods of Buddhist arts adhering to one another such as the Dvaravati Period, particularly art objects in Maha Sarakham, Kalasin and Roi Et in northeast Thailand. There have been the Buddha images adhering to one another in the next 3 periods, i.e., the Dvaravati period, the Lop Buri Period and the Lan Chang Period. In particular during the Dvaravati Period, the sandstone Buddha images in different sizes including baked-clay amulets and bronze Buddha images were made and kept in large-sized stupas in the middle of towns. During the Lop Buri Period, they made a great number of the Buddha images

Corresponding Author: Athikan Suksri, The Research Institute Northeastern of Art and Culture, Mahasarakham University, Thailand 
in a style with naga (snake) over his head, Phra Vajaradhorn, graven image sand places of worship in Hinduism. Some examples are Ku (stupa) Santarat, Ku Noi Sala Nang Khao, Ku Kasing and Ku Phra Kona. During the Lan Chamg Period, there appeared cast mortar Buddha images, bronze Buddha image sand wooden Buddha images scattering throughout the provinces mentioned. All of the Buddha images as mentioned were made for use in supplement to religious ritual performance. These art objects can be seen as Buddhist art in Isan but they lack care and conservation, causing the value of art objects to decrease; craftsmen of the elder generation are discouraged and craftsmen of new generation lack motivation for creating Buddha image art and for adhering to local indigenous knowledge of Isan people.

\section{MATERIALS AND MATHODS}

The qualitative research methodology was used. Data were gathered from related literature and filed studies by interviews using structured-and unstructuredinterview forms and focused group discussion. Totally 66 informants consisted of a group of 9 key informants and experts in Buddha image art, a group 20 craftsmen and sculptors, a group of 19 image keepers and a group of 18 general villagers. Findings were presented by means of a descriptive analysis.

\section{RESULTS}

The backgrounds of types and the Buddha image characteristics and iconology of the Buddha images in Isan, Thailand. For the Buddha images as discovered in the research area, they were made in 3 Periods: The Dvaravati, Lop Buriand Lan Chang Periods. In each Period there were 4 types of the Buddha images: sandstone Buddha images, baked-clay votive tablets, cast motar Buddha images, bronze Buddha images and wooden Buddha images. The sandstone Buddha images as appearing include: Phra Buddha Ming Mangala, the Mangala standing Buddha Image, the Reclining Buddha, the concentration-style Buddha images and the naga-over-His-head Buddha images. The Buddha images in the type of baked-clay votive tablets could be categorized according to their characteristics into 4 styles: Standing to give a sermon, sitting with hanging legs to give a sermon, sitting on flat haunches and sitting on cross-legged haunches. The baked-clay votive tablets on plates are in the rectangular form and other forms such as leaves and flames. The cast motar Buddha images were found in the Lan Chang Period only by local craftsmanship mixing with capital city craftsmanship. Only the maravijaya style was found situated in sim or bot. The bronze Buddha images were found in the Periods of Dvaravati, Lop Buriand Lan Chang. The styles popularly built were the dharma giving and concentration styles, while the maravijaya style was found the most. The wooden Buddha images were made in the Thai-Lao culture Period. They popularly built the images in the styles of maravijaya, concentration, blessing and relatives-stop, worldopening, bowl-holding and dharma consideration.

In iconology, most of the Buddha images built were in the styles relating to the stories of the Lord Buddha such as The Enlightenment and absolute happiness (Nirvana), showing double miracles and giving dharma. All of the iconology of the Buddha images came from the stories of the Lord Buddha, frequently taken from the scriptures of Buddhism including Pali Arthakatha scripture, Sanskrit Divayavadana Scripture in Sarvativada Sect and the Vinaya Pitaka of the Mulasarvastivada Sect. The highlights easy for creation were selected. The sandstone Buddha images were in the styles of blessing and absolute happiness (Nirvana). The baked-clay votive tablets were in the styles of the Enlightenment, showing double miracles to suppress heathens in the mango forest in Savathi City, going to preach dharma to His Mother to be free from sin (leaving Tavatingsa). The cast motar Buddha images were in the styles of the Enlightenment and absolute happiness (Nirvana). The wooden Buddha images were in the styles of the Enlightenment, facing the Evil (maravijaya), relativesstop and dharma consideration.

Current conditions of the Buddha images: The Buddha images are currently mismanaged without giving the importance to them because of advancements and modernization in other aspects. For the current conditions, the sandstone Buddha images are placed in the group of Dvaravati art mixed with folk art. Their outstanding characteristics are: The standing body of the Buddha image is leaning in the trashing posture (3 parts); the reclining Buddha image is on the carved pedestal on the cliff. Significant characteristics include: The hair top is a crest knot; hair knots are big and obtuse without hair dots; the forehead is continuously twisted in a form of long braces; the face is flat and wide; the lips are wide out and the chin is obtuse. The robe is thin, pressing to the body. The end of the outer robe is long down to the navel. The sandstone Buddha images were influenced from Bayon (Lop Buri) art. Their outstanding characteristics include: Hair knots are like shellfish spirals, or a dish cover, or the crown of the god image and made in the snake-over-His-head 
style. The face expresses a deep and peaceful smile. The upper edge of the sarong has crests. The ears are long, wearing fish shell-spiral-shape ear-rings. The height is longer than the width. For the characteristics of the baked-clay votive tablets, the radi are in the form of the budding lotus; the hair top is a crest knot, hair dots are big fish shell-spirals without hair lines on the forehead. The nose is rather pointed. The eyes are protruding ones, looking downwards. The ears are long down to the shoulders. The body is fat and round, sitting with cross legs in cross-legged and flat crosslegged postures and sitting with hanging leg (s). The standing Buddha votive tablets are in the trashing posture in the walking style. In addition, there are other factors such as trees and leaves, particularly the Sri Maha Bodhi Tree and the tree and leaves of Barringtonia, figure of persons wearing the king's clothes and naga with 7 heads. The stupa model and the relief single stupa model are on the baked-clay votive tablets. The characteristics of the cast motar Buddha images are found only in the Period of Thai-Lao Lan Chang culture. Significant characteristics of the Buddha images include: Radi over the head are flames; hair top is a crest knot; hair dots are like jack-fruit thorns; the face is round with and without lines of hair on the forehead; the eye-brows join together behind the plump eyes and the nose is straight and pointed. The cast motar Buddha image wears a robe across the shoulder, with the outer robe-end mostly hanging above the stomach, sitting with flat cross legs on the cast motar base. The characteristics of the bronze Buddha images can be divided into 3 groups. The Buddha images influenced by the Dvaravati art have the following outstanding characteristics: Hair top with crest, big hair dots without lines of hair on the fore head, a round face, a round neck, wearing neat robes without an outer robe, showing the blessing style with a single hand, equally long fingers and broken and lost base. For the characteristics, the Buddha image has head radi of flames, without lotus petals, hair dots with small thorns of shellfish spirals, a square face, small and long ears with curve-out ear ends, a round and segmented neck, a straight and pointed nose, big shoulders and chests, protruding breasts, a big outer robe with a straight end, equally long fingers and equally long and flat toes; sitting on the round pedestal. For the bronze Buddha images of the Lan Chang art, the characteristics are; head radi with flames or with lotus petals around the radi on the head; hair dots are in the shape of small fish shell spiral like jack-fruit thorns with lines of hair on the forehead. The eye-brows are curved with high ridges lying apart from each other. The nose is straight and pointed with little low end. The ears are curly. The neck is segmented. The shoulders are small. The chests are rather wide. The breasts are protruding with several layers. The outer robe is made into a rather big stripe and its end is cut straight. The fingers are equally long. The feet are flat, sitting with cross-legged posture. For the wooden Buddha images, their outstanding characteristics include: In proportional shape according to the anatomic principle because the craftsmen created them based on their own imaginations and due to mainly limitation of each piece of wood. The other significant characteristics of the Buddhist art are: The radi are in the forms of budding lotus or the pointed cylinder; the hair top is in the round shape or without the hair top at all; mostly without hair dots, but often with lines of hair on the forehead as a frame; wearing flat robes without stripes; the outer robe end being above the navel. The hands and feet are plates while the fingers are equally long.

In comparing Buddhist art between the 2 sources in the same periods beginning from the Dvaravati Period, the Lop Buri Period and the Lan Chang Period, in Mueang Kantharawichai the Buddha images of the Lop Buri Period did not appear at all. The Buddha images found here are of the Dvaravati Period. The radi on the head have budding lotus and flames. The hair top is crest. The eye-brows join together like braces. The nose is straight and pointed. The mouth is wide. The eyes are protruding. The hair dots are big and obtuse in the fish shell spirals without lines of hair on the forehead. The Buddha images of the Davaravati period wear neat and flat robes without an outer robe. Those of the Lan Chang Period have a straight outer robe end above the navel without patterns. The standing Buddha images of the Dvaravati Period were popularly made in the blessing styleand the Buddha images with naga-overHis-head were made in the Lop Buri Period. In this period, they popularly made naga-over-His-head Buddha images and baked-clay votive tablets which are like the characteristics of the baked-clay votive tablets found in Mueang Nakhon Pathom, Mueang Khu Bua and Mueang Hariphunchai. In particular, the characteristics of the face and environmental compositions of the votive tablets are often found to have stupas, or regalia, or Bo arches in similarity. In the Lan Chang period the cast motar Buddha images were popularly made in the maravijaya style by folk craftsmen mixed with capital city craftsmen and local craftsmen, particularly, the characteristics of radi, the hair top, the face and the basses. The bronze Buddha images were found to be in the Dvaravati Period and the Lan change period. They have characteristics like Lan Chang art. The styles of the wooden Buddha images popularly built are the maravijaya style, 
concentration style and dharma consideration style. They are local craftsmanship's developed from Royal craftsmen and local craftsmen regardless Buddha image characteristics as they should.

Guidelines for conservation and adherence to the Buddha images: Due to the ancient Buddha images are properties of the community, thus conservation and adherence to Buddhist art can be done in 2 major ways: Conservation of the ancient Buddha images to be in existence in the beautiful condition everlastingly and transference of the process of creating the Buddha images both traditionally and applying the ancient Buddhist art to modernization. This conservation should not be the duty of monks only to take care of the Buddha images but the community and local administrative organizations should also participate in conservation. There should be dissemination of the local important Buddha images as well as developing the monastery to be a tourist attraction. As for the adherence, there should be organization of training in creation of the local Buddha images to craftsmen and sculptors in order to transfer techniques of creating the Buddha images and transferring them to local young people in the future (Natsupa, 1995).

\section{DISCUSSION}

All of the Buddha image art found has its own identity in each period. The sandstone Buddha images have the characteristics of the Dvaravati art that Isan has received the Dvaravati art through Central Thailand because the Buddha images of the Dvaravati Period found have the characteristics, particularly the radi above the head, hair top, hair dots, lines of hair on the forehead, eye-brows, nose, mouth and lips and the body, robe wearing and trashing standing posture of the Dvaravati art, Indian influence mixed with the identity of local craftsmen that the characteristics of the head of the Buddha images of the Dvaravati Period often have a round or square face, protruding eyes, joined eyebrows, a wide mouth, round and big hair with hair top. The Buddha images of the Dvaravati art in the early batches were influenced by India. Later, there have been developments using local art to mix with them. The Buddha images in the Lop Buri Period and the Lan Chang Period, the cast motar Buddha images, the bronze Buddha images and wooden Buddha images were then influenced by Lan Chang art. Since the middle of the sixteenth century there have been extensions of people and towns in Isan. As a result, the Buddha images built during this period were also influenced by Lan Chang. Many Phra Bang type
Buddha images in the relatives-stop style can be often found in Isan region (Pradharmakosajan, 2006).

\section{CONCLUSION}

This study of the Buddha images and conservation and adherence to cultural values in Isan aimed to examine backgrounds of the characteristics of the Buddha images and iconology of the Buddha images in 5 models: The sandstone Buddha imager, baked-clay votive tablets, cast motar Buddha images, bronze Buddha imagesand wooden Buddha images appearing in Isan in Changnwat Maha Sarakham, Changwat Kalasinand Changwat Roi Et. These 3 provinces have long backgrounds and developments and have Buddha image art generated from prosperity in 3 major periods: The Dvaravati period, the Lop Buri period and the Lan Chang Period. The styles most popularly built are the concentration style, the naga-above-his-head style, the blessing style, the double miracles style and the dharma consideration style. All these styles are obtained from the stories of the Lord Buddha throughout His life. The materials used for making these images are sandstone, baked-clay, cast motar, bronzeand wood. These things are local Isan heritages and identities (Thongwol et al., 2010; Southern Region Teacher College Group, 1983).

\section{ACKNOWLEDGEMENT}

The researchers express their sincere appreciation for all of support provided.

\section{REFERENCES}

Natsupa C., 1995. Culture and Social Changing Process. Chulalongkorn University Printing Office, Bangkok, ISBN: 978-975-9681, pp: 99-2.

Pradharmakosajan, 2006. (Prayoon Dharmajitto) Buddhism Management Technique. 1st Edn., Mahachulalongkorn Rachawittayalai Printing, Bangkok, ISBN: 978-974-9900-12-3, pp: 230

Southern Region Teacher College Group, 1983. Amulet Really Providing Advantage and Disadvantage: Supernatural Power. 1st Edn., No Publishing Company, Bangkok, ISBN: 974-333-607-9, pp: 217.

Thongwol, N., J. Tammawat, P. Rithidej and B. Saenyabud, 2010. The social movement of the Puan in Thailand. J. Soc. Sci., 2: 293-295. 